\title{
PERENCANAAN DAN PENGENDALIAN UNTUK KREDIT KEMITRAAN DI PT. BANK BUKOPIN CABANG MANADO
}

\author{
Margarietha S. A. Manumpil ${ }^{1}$, Harijanto Sabijono ${ }^{2}$, Lidia M. Mawikere ${ }^{3}$ \\ 1,2,3 Jurusan Akuntansi, Fakultas Ekonomi dan Bisnis, Universitas Sam Ratulangi, Jl. Kampus Unsrat Manado, \\ 95115, Indonesia
}

E-mail: margariethamanumpi19@gmail.com

\begin{abstract}
Banks are institutions that act as financial intermediaries, as a vital means of supporting the smooth running of the economy, in their function of transferring funds from savers or surplus units to borrowing partners or deficit units. Credit control is efforts to keep the credit provided smooth, productive and non-performing. Current and productive means the credit can be withdrawn with interest according to the agreement agreed by both parties. The purpose of this study was to determine the planning and control of partnership credit at PT. Bank Bukopin Manado Branch. And the type of research used is descriptive qualitative approach data, namely data presented descriptively in the form of a description such as the writer's observations during the study in the form of interviews and observations, and presented in the form of data not in the form of numbers. The results showed that credit planning conducted by PT. Bank Bukopin Manado Branch is very well established. This can be seen from the credit budget set from 2017 to 2018 which has increased every year and the implementation of credit control of PT. Bank Bukopin Manado is implemented very well, this can be seen from the targets achieved from 2017 to 2018 experiencing growth every year.

Keywords: planning; control; credit; partnership credit; control credit; PT. Bank Bukopin Manado
\end{abstract}

\section{PENDAHULUAN}

Bank merupakan lembaga yang berperan sebagai perantara keuangan (financial intermediaries), sebagai sarana pendukung yang amat vital untuk menunjang kelancaran perekonomian, dalam fungsinya mentransfer dana-dana (loanable fund) dari penabung atau unit surplus (lenders) kepada peminjam (borrower) atau unit defisit. Lembaga perbankan ini pula yang menjadi pusat dan urat nadi mekanisme peredaran uang yang akan menggerakkan roda pembangunan. Jika dilihat dari sisi pemerintah, maka lembaga perbankan merupakan sarana untuk melaksanakan kebijakan ekonomi dan keuangan yang ditujukan pada usaha tercapainya stabilitas ekonomi nasional yang baik. Bank mempunyai peran vital bagi suatu negara dalam usaha memajukan perekonomian.

Usaha Mikro, Kecil, dan Menengah adalah sebuah usaha ekonomi produktif yang memiliki jumlah kekayaan dan penjualan tahunan tertentu dan hal tersebut diatur dalam Undang-Undang untuk menentukan kategori usaha tersebut. Usaha Mikro, Kecil, dan Menengah (UMKM) telah menjadi tulang punggung perekonomian Indonesia. Sejarah membuktikan, ketika terjadi krisis moneter pada tahun 1997 banyak usaha besar yang tumbang karena dihantam krisis tersebut, namun UMKM tetap berjalan dan menopang kelanjutan perekonomian Indonesia. Bank adalah badan usaha yang menghimpun dana dari masyarakat dalam bentuk simpanan dan menyalurkan kepada masyarakat dalam bentuk kredit dan lain-lain dalam rangka meningkatkan taraf hidup masyarakat.

Pengendalian kredit adalah usaha untuk menjaga kredit yang diberikan tetap lancar dan produktif sehingga tidak terjadi kredit macet. Lancar dan produktif artinya kredit itu dapat ditarik kembali bersama bunganya sesuai dengan perjanjian yang telah disetujui kedua 
belah pihak. Hal ini penting karena jika kredit macet berarti kerugian bagi bank yang bersangkutan, oleh karena itu, penyaluran kredit harus didasarkan pada prinsip kehati-hatian dan dengan sistem pengendalian yang benar. Sebagian besar bank mempergunakan teknik untuk melakukan pengendalian (pengawasan) guna menghindari resiko dalam pemberian kredit dan salah satu bank yang selalu melakukan pengendalian atas kredit yang diberikannya kepada masyarakat atau mitra adalah PT. Bank Bukopin Cabang Manado.

Pemberian pinjaman kepada calon mitra binaan dilakukan melalui proses pengajuan kredit dan analisis terhadap kredit yang diajukan. Perusahaan dapat melakukan analisis permohonan kredit calon mitra binaan apabila semua persyaratan yang ditetapkan oleh perusahaan telah terpenuhi. Selain kelengkapan data pendukung permohonan kredit, perusahaan juga melakukan penilaian kelengkapan dan kebenaran informasi dari calon mitra binaan, serta melaksanakan prinsip sesuai dengan kebijakan prosedur pemberian kredit yang ada. Bank Bukopin Cabang Manado adalah Bank Swasta Nasional yang didirikan pada tanggal 10 Juli 1970. Dalam kegiatan bisnisnya Bank Bukopin memfokuskan diri pada segmen Usaha Mikro, Kecil, dan Menengah (UMKM).

\section{TINJAUAN PUSTAKA}

Menurut Rudianto (2012:4), akuntansi adalah seni dalam mengukur, berkomunikasi dengan lembaga pemerintah. Akuntansi merupakan sistem informasi yang menghasilkan informasi keuangan kepada pihak-pihak yang berkepentingan mengenai aktivitas ekonomi dan kondisi suatu perusahaan. Tujuan akuntansi itu sendiri, yaitu menyajikan informasi ekonomi dari suatu entitas atau kesatuan ekonomi kepada pihak-pihak yang berkepentingan atas informasi ekonomi.

Menurut Tuanakotta (2014:127), pengendalian adalah pengendalian internal dirancang, diimplementasi, dan dipelihara oleh TCWG, manajemen, dan karyawan lain untuk menangani risiko bisnis dan risiko kecurangan yang diketahui (identified business and fraud risk) mengancam pencapaian tujuan entitas, seperti pelaporan keuangan yang andal. Pengendalian selalu merupakan jawaban (response) untuk menangkal (mitigate) suatu ancaman (kemungkinan terjadinya risiko). Pengendalian yang tidak merupakan jawaban untuk menangkal ancaman, adalah kesia-sian (redundant). Langkah pertama dalam mengevaluasi rencana pengendalian adalah, tentukan risiko apa yang perlu ditangkal. Langkah kedua, tentukan pengendalian yang ada untuk menangkal risiko tersebut.

Menurut Firdaus dan Ariyanti (2017: 2), kredit adalah suatu reputasi yang dimiliki seseorang, yang memungkinkannya bisa memperoleh uang, barang-barang atau tenaga kerja/buruh, dengan jalan menukarkannya dengan suatu janji untuk membayarnya disuatu waktu yang akan datang. Sedangkan menurut Undang-Undang Nomor 10 tahun 1998 pasal 1:1 tentang perubahan atas Undang-Undang Nomor 7 tahun 1992 tentang perbankan kredit adalah kredit adalah penyediaan uang atau tagihan yang dapat dipersamakan dengan itu, berdasarkan persetujuan atau kesepakatan pinjam-meminjam antara bank dengan pihak lain yang mewajibkan pihak peminjam untuk melunasi utangnya setelah jangka waktu tertentu dengan pemberian bunga. Keuntungan merupakan tujuan dari pemberian kredit yang diterima dalam bentuk bunga. Pancasila adalah dasar falsafah negara kita, maka tujuan kredit tidak semata-mata mencari keuntungan, melainkan disesuaikan dengan tujuan negara yaitu untuk mencapai masyarakat adil dan makmur berdasarkan Pancasila (Suyatno et al., 2007: 14).

Kasmir (2012:105) mendefinisikan prosedur pemberian kredit adalah sebelum debitur memperoleh kredit terlebih dahulu harus melalui tahapan-tahapan penilaian mulai dari pengajuan proposal kredit dan dokumen-dokumen yang diperlukan, pemeriksaan keaslian dokumen, analisis kredit sampai dengan kredit dikucurkan secara bertahap. Dalam memberikan kredit ini dikenal nama prosedur pemberian kredit. Tiap bank mempunyai cara sendiri tentang pengajuan dan penyelesaian permintaan kredit. Menurut Suyatno et al. 
(2007:69), ketentuan umum perkreditan, prosedur pemberian kredit terdiri dari tahap-tahap permohonan kredit, penyidikan dan analisa kredit, keputusan atas permohonan kredit, pencairan fasilitas kredit dan pelunasan fasilitas kredit.

Tohar (2000: 109) mendefinisikan kemitraan adalah teman, sahabat, kawan kerja, pasangan kerja, dan rekan. Kemitraan artinya perihal hubungan atau jalinan kerjasama sebagai mitra. Kemitraan merupakan hubungan kerjasama usaha berbagai pihak yang sinergis, bersifat sukarela, dan berdasarkan prinsip saling membutuhkan, saling mendukung, dan saling menguntungkan dengan disertai pembinaan dan pengembangan Usaha Mikro Keccil Menengah (UMKM) oleh usaha besar dengan tujuan yaitu meningkatkan pendapatan usaha kecil dan masyarakat, meningkatkan perolehan nilai tambah bagi pelaku kemitraan, meningkatkan pemerataan dan pemberdayaan masyarakat, meningkatkan pertumbuhan ekonomi pedesaan, wilayah dan nasional, memperluas kesempatan kerja dan meningkatkan ketahanan ekonomi nasional.

Menurut Tambunan (2012:2), UMKM adalah unit usaha produktif yang berdiri sendiri, yang dilakukan oleh orang perorangan atau Badan Usaha disemua sektor ekonomi. Pada prinsipnya, pembedaan antara Usaha Mikro (UMi), Usaha Kecil (UK), Usaha Menengah (UM) dan Usaha Besar (UB) umumnya didasarkan pada nilai aset awal (tidak termasuk tanah dan bangunan), omset rata-rata per tahun atau jumlah pekerja tetap. UMKM memainkan peran-peran penting didalam pembangunan dan pertumbuhan ekonomi, tidak hanya di negara-negara sedang berkembang (NSB), tetapi juga di 20 negara-negara maju (NM). NM, UMKM sangat penting tidak hanya karena kelompok usaha tersebut menyerap paling banyak tenaga kerja dibandingkan dengan usaha besar (UB). Khususnya Asia, Afrika, dan Amerika Latin, UMKM juga berperan sangat penting khususnya dari perspektif kesempatan kerja dan sumber pendapatan bagi kelompok miskin, distribusi pendapatan dan pengurangan kemiskinan, serta pembangunan ekonomi pedesaan (Tambunan, 2017:1).

Fernos (2014) menunjukkan bahwa perencanaan dan pengendalian kredit di PT. BPR Echo Coastal dapat menurunkan kredit macet setiap tahun dari 0,54\% pada 2006 menjadi 0,31\% pada 2010. Ernawati dan Katherina (2017) menunjukkan bahwa dalam meminjamkan modal hanya mengejar target manajemen yang membiarkan menyebabkan distribusi modal yang tidak efisien dan membuat perusahaan kurang teliti dalam analisis kredit konduktif. Rinaldo (2016) menunjukkan bahwa sebagian besar peserta pelatihan awalnya tidak memahami penerapan alat-alat analisis dalam perencanaan dan pengendalian keuangan dalam bisnis mereka dan setelah mengikuti pelatihan pengetahuan peserta pelatihan terkait perencanaan dan pengendalian keuangan mengalami peningkatan namun belum signifikan. Ghassani (2015) menemukan bahwa kemitraan PT. PJB Unit Gresik secara keseluruhan dirasa kurang optimal dalam melakukan pelaksanaan program CSR dan belum sesuai dengan Surat Keputusan Menteri BUMN No. Kep-236/2003 dan SE/433/M-MBU/2003 tentang Kemitraan dan Bina Lingkungan dan juga belum sesuai dalam Undang-undang Nomor 40 tahun 2007, pasal 74 tentang tanggung jawab sosial perusahaan.

\section{METODE PENELITIAN}

Jenis penelitian yang digunakan adalah data deskriptif kualitatif yaitu data yang disajikan dalam bentuk penjelasan secara jelas dan terperinci. Temuan kualitatif diarahkan untuk menghasilkan perbaikan-perbaikan mutu kerja dan pada dasarnya pula bermanfaat untuk kepentingan akademis (Indrawan dan Yaniawati, 2014:68). Penelitian ini menggunakan data primer yang diperoleh secara langsung dari objek penelitian melalui wawancara langsung dengan pegawai dan juga pimpinan dari objek penelitian, yaitu PT. Bank Bukopin Cabang Manado. Metode analisis yang digunakan dalam penelitian ini adalah metode analisis deskriptif, yaitu suatu metode yang dilakukan dengan cara mengumpulkan, menyajikan, serta menganalisis data sehingga diperoleh gambaran yang cukup jelas tentang 
masalah yang dihadapi, kemudian ditarik suatu kesimpulan sesuai keadaan yang sebenarnya. Penelitian desktiptif adalah sebuah penelitian yang bertujuan untuk memberikan atau menjabarkan suatu keadaan atau fenomena yang terjadi saat ini dengan menggunakan prosedur ilmiah untuk menjawab masalah secara aktual (Sugiyono, 2016).

\section{HASIL PENELITIAN DAN PEMBAHASAN}

\subsection{Hasil penelitian}

Proses pemberian kredit yang dilakukan oleh PT. Bank Bukopin berpedoman dan mengikuti ketentuan-ketentuan yang ditetapkan oleh PT. Bank Bukopin dan UU Perbankan, serta peraturan-peraturan yang dikeluarkan oleh BI dan instansi - instansi pemerintah lainnya. Dalam pemberian kredit pihak debitur mengajukan permohonan kredit kepada PT. Bank Bukopin, dari permohonan yang diajukan oleh pihak debitur, PT. Bank Bukopin melakukan identifikasi dan pengumpulan data-data dari pihak debitur setelah itu dilakukan analisa kredit dan rekomendasi dari pihak debitur. Dari identifikasi dan pengumpulan data serta analisa kredit dan rekomendasi dari pihak debitur baru PT. Bank Bukopin memutuskan diterima atau tidaknya permohonan kredit yang diajukan oleh debitur. Jika pihak bank menerima permohonan dari debitur baru perjanjian kredit dilakukan antara debitur dengan pihak PT. Bank Bukopin. Setelah perjanjian dilakukan maka tahapan berikutnya adalah realisasi perjanjian, dari realisasi ini data pemohon, serta syarat kelengkapan lainnya diinput kedalam database PT. Bank Bukopin dan membuat pelaporan transaksinya. Setelah pelaporan dilakukan dan pihak debitur menerima dana kredit yang disepakati dalam hal ini pihak bank tidak langsung lepas tangan. Pihak PT. Bank Bukopin selama masa kreditnya memberikan pengawasan dan pembinaan kepada debitur supaya dana yang telah diberikan dapat benarbenar dimanfaatkan dengan sebaik-baiknya, dan dalam masa pengawasan dan pembinaan ini penagihan dan restrukturisasi serta upaya lainnya dilakukan.

\subsection{Pembahasan}

Perencanaan kredit pada PT. Bank Bukopin adalah merupakan tugas dari administrasi kredit. Administrasi kredit menyusun perencanaan dari kredit yang akan disalurkan kepada debitur dengan menetapkan beberapa aturan-aturan pokok dan dengan berbagai pertimbangan dari faktor eksternal dan internal perusahaan. Perencanaan disusun setelah laporan keuangan untuk tahun yang berakhir 31 Desember telah disusun. Sebagai salah satu bentuk dari perencanaan, hasil dari laporan keuangan tersebut tujuannya adalah untuk melihat posisi keuangan dari perusahaan guna menetapkan anggaran kredit yang akan direalisasikan pada tahun berikutnya. Berikut dapat dijelaskan bentuk perencanaan kredit dari PT. Bank Bukopin, yaitu:

1. Penilaian keadaan, dimana penilaian keadaan intern perusahaan, meliputi kekuatan dan kelemahan intern baik itu dari sarana dan prasaran serta SDM-nya. Dan penilaian kepada keadaan ekstern dari perusahaan, meliputi keadaan ekonomi pada umumnya, kondisi pasar, pesaing, kebijakan pemerintah, peluang perluasan pemberian kredit akibat dari meluasnya usaha, dan asumsi kemungkinan dugaan-dugaan keadaan yang mungkin terjadi di waktu yang akan datang.

2. Menyusun basis data guna dilakukannya penyusunan database ini adalah untuk memberi gambaran mengenai data dasar meliputi data-data kredit, biaya-biaya dan dana.

3. Menetapkan strategi, dimana suatu upaya bagaimana tujuan perencanaan dapat dicapai dengan mempergunakan sumber-sumber yang dimiliki oleh suatu bank, dan diusahakan pula untuk mengatasi kesulitan-kesulitan serta tantangan yang ada. Guna ditetapkan strategi untuk menyusun target, program, dan proyek untuk mewujudkan tercapai tujuan serta tugas pokok perencanaan. 
4. Pelaksanaan perencanaan, dimana dilakukan berdasarkan target atau program yang telah direncanakan yaitu berupa pengalokasian kredit ke sektor-sektor atau proyek yang perlu mendapatkan pembiayaan.

Persiapan dari pelaksanaan perencanaan kredit di PT. Bank Bukopin Cabang Manado adalah: (1) pelaksanaan dilakukan oleh unit pemberian kredit sedangkan pengerahan dana oleh unit pengerahan dana; (2) strategi perencanan sebagai dasar ketentuan-ketentuan kebijaksanaan perkreditan seperti kebijaksanaan jenis kredit, bunga, prioritas nasabah yang akan memperoleh kredit; (3) penyusunan kembali organisasi perkreditan; (4) penyusunan formulir permohonan; (5) penentuan wewenang memutus persetujuan pemberian kredit; (6) ketentuan jaminan; (7) ketentuan penarikan dan pelunasan; (8) ketentuan penagihan; dan (9) ketentuan penyelesaian kredit yang macet.

Pelaksanaan perencanaan kredit pada PT. Bank Bukopin Cabang Manado ini mengacu pada: (1) penilaian terhadap permohonan kredit harus didasarkan pada ketentuanketentuan yang berdasarkan pada strategi perencanaan; (2) alokasi kredit harus berdasarkan pada batas-batas jumlah sesuai dengan program; dan (3) walaupun terdapat program alokasi yang telah ditetapkan. Namun realisasi pemberian kredit harus mengingat pula kemungkinan pengerahan dana. Melakukan pengendalian kredit yaitu untuk menjaga kredit yang diberikan tetap lancar, produktif dan tidak ada kredit macet. Hal ini sangat penting karena jika kredit macet berarti merugikan pihak bank. Dilakukannya pengendalian kredit setelah kredit diberikan kepada debitur. Pelaksanaan pengendalian kredit pada PT. Bank Bukopin Cabang Manado yaitu melalui pengendalian internal dan eksternal. Pengendalian internal kredit dari PT. Bank Bukopin Cabang Manado yaitu:

1. Organisasi.

a. Bagian kredit terpisah dari bagian akuntansi.

b. Petugas analisis kredit yang menganalisa permohonan kredit tidak hanya satu orang.

c. Transaksi keluar masuknya uang dilaksanakan oleh bagian kasir dan bagian pembukuan. Tidak ada suatu bagian yang menangani satu transaksi secara lengkap.

2. Sistem otoritasi dan prosedur pencatatan.

a. Formulir permohonan kredit diotorisasi oleh Kabag Marketing setelah dianalisa oleh petugas analisis.

b. Perjanjian kredit diotorisasi oleh Direksi dengan membubuhkan tanda tangan otorisasi dalam warkat kredit.

c. Pencatatan dalam jurnal pengeluaran kas didasarkan pada bukti pengeluaran kas yang dikeluarkan oleh kasir.

3. Praktik yang sehat.

a. Seluruh keuangan yang terjadi dicatat secara periodik setiap hari.

b. Kasir dilengkapi dengan alat pendeteksi uang palsu dan brankas untuk mengamankan kas.

c. Secara periodik bagian akuntansi mengadakan rekonsiliasi catatan pembayaran angsuran menurut buku pembantu harian kredit dengan rekening kontrol pembayaran angsuran kredit dalam buku besar.

d. Secara periodik dilakukan pengawasan dari atasan terhadap pekerjaan bawahannya.

Perencanaan kredit pada PT. Bank Bukopin dalam operasionalnya terealisasikan dengan sangat baik hal ini dapat dilihat pada Tabel 1 tentang realisasi pemberian kredit menurut jenis penggunaan, realisasi pemberian kredit menurut sektor ekonomi dan realisasi pemberian kredit menurut kolekbilitas. 
Tabel 1. Realisasi pemberian kredit menurut jenis penggunaan tahun 2017 (dalam Rp.)

\begin{tabular}{lrrr}
\hline Jenis Penggunaan & \multicolumn{1}{c}{ Anggaran } & \multicolumn{1}{c}{ Realisasi } & Percentage \\
\hline Modal Kerja & $710.000 .000 .000,00$ & $767.807 .283 .562,89$ & $108.14 \%$ \\
Investasi & $80.000 .000 .000,00$ & $97.479 .234 .284,46$ & $121.85 \%$ \\
Konsumsi & $15.000 .000 .000,00$ & $19.231 .632 .182,42$ & $128.21 \%$ \\
\hline Total & $\mathbf{8 0 5 . 0 0 0 . 0 0 0 . 0 0 0 , 0 0}$ & $\mathbf{8 8 4 . 5 1 8 . 1 5 0 . 0 2 9 , 7 7}$ & \\
\hline
\end{tabular}

Sumber: PT. Bank Bukopin Manado tahun 2017

Menurut jenis penggunaan untuk tahun 2017 diketahui bahwa kredit yang disalurkan terealisasikan dengan baik, hal ini dapat dilihat dari total anggaran kredit yang ditetapkan pada perencanaan kredit menurut jenis penggunaan untuk tahun 2017 adalah sebesar Rp. 805.000.000.000,00 yang terealisasikan ke masyarakat adalah sebesar Rp. 884.518.150.029,77. Pada kredit untuk modal kerja pada tahun 2017, anggaran yang ditetapkan dalam perencanaan kredit adalah sebesar Rp. 710.000.000.000,00 yang terealisasikan ke masyarakat adalah sebesar Rp. 767.807.283.562,89. Anggaran yang ditetapkan dalam perencanaan kredit untuk tahun 2017 pada kredit untuk investasi adalah sebesar Rp. 80.000.000.000,00, yang terealisasikan ke masyarakat adalah sebesar Rp97.479.234.284,46. Pada kredit untuk konsumsi adalah sebesar Rp. 15.000.000.000,00, yang terealisasikan ke masyarakat adalah sebesasr Rp. 19.231.632.182,42.

Tabel 2. Realisasi pemberian kredit menurut jenis penggunaan tahun 2018 (dalam Rp.)

\begin{tabular}{lrrr}
\hline & \multicolumn{1}{c}{ Anggaran } & \multicolumn{1}{c}{ Realisasi } & Percentage \\
\hline Modal Kerja & $850.000 .000 .000,00$ & 687.103 .439 .823 .99 & $80.84 \%$ \\
Investasi & $90.000 .000 .000,00$ & 77.550 .808 .250 .68 & $86.17 \%$ \\
Konsumsi & $25.000 .000 .000,00$ & 17.982 .329 .953 .38 & $71.93 \%$ \\
\hline Total & $\mathbf{9 6 5 . 0 0 0 . 0 0 0 . 0 0 0 , 0 0}$ & $\mathbf{7 8 2 . 6 2 6 . 5 7 8 . 0 2 8 , 0 5}$ & \\
\hline
\end{tabular}

Sumber: PT. Bank Bukopin Manado tahun 2018

Tabel 2 menunjukkan bahwa realisasi pemberian kredit menurut jenis penggunaan untuk tahun 2018 diketahui bahwa kredit yang disalurkan terealisasikan dengan baik, hal ini dapat dilihat dari total anggaran kredit yang ditetapkan pada perencanaan kredit untuk tahun 2018 menurut jenis penggunaan yaitu sebesar Rp. 965.000.000.000,00 yang terealisasikan ke masyarakat adalah sebesar Rp. 782.626.578.028,05. Pada kredit untuk modal kerja pada tahun 2018, anggaran yang ditetapkan dalam perencanaan kredit adalah sebesar Rp. 850.000.000.000,00 dan kredit yang terealisasikan ke masyarakat adalah sebesar Rp. 687.103.439.823,99. Anggaran yang ditetapkan dalam perencanaan kredit untuk tahun 2018 pada kredit untuk investasi adalah sebesar Rp. 90.000.000.000,00, yang terealisasikan ke masyarakat adalah sebesar Rp. 77.550.808.250,68. Dan anggaran yang ditetap dalam perencanaan kredit untuk tahun 2018 kredit untuk konsumsi adalah sebesar Rp. 25.000.000.000,00, yang terealisasikan ke masyarakat adalah sebesar Rp, 17.982.329.953,38.

Pelaksanaan pengendalian kredit dari PT. Bank Bukopin Cabang Manado bisa dikatakan sudah sangat baik, karena bank tidak saja melakukan pengendalian dari internal perusahaannya saja tetapi juga pengendalian ekternal dari perusahaannya. Perusahaan selalu melakukan pemantaun dari usaha nasabahnya sehingga terjadi komunikasi yang berkelanjutan antara kreditur dengan debitur. Bank melihat kemajuan-kemajuan yang dialami oleh debitur dalam melaksanakan kegiatan-kegiatannya setelah kredit diberikan, sehingga dalam pembayaran angsuran pinjaman dan bunga pinjaman tidak mengalami kendala yang berarti sesuai dengan jadwal dan jangka waktu yang telah disepekati dalam perjanjian kredit.

Perencanaan kredit pada PT. Bank Bukopin Cabang Manado adalah merupakan tugas dari administrasi kredit. Berdasarkan kepada bentuk-bentuk perencanaan kredit pada PT. 
Bank Bukopin Cabang Manado ini bisa dikatakan bahwa perencanaan kredit untuk satu tahun buku ke depan sudah baik dan matang, dan jika dilihat kepada tujuan pokok dari perencanaan kredit pada PT. Bank Bukopin Cabang Manado bisa dikatakan bahwa perencanaan yang ditetapkan masuk akal dan akan memberikan hasil yang memuaskan nantinya bagi kelangsungan usaha bank. Dilihat dari persiapan dari pelaksanaan perencanaan kredit di PT. Bank Bukopin Cabang Manado sudah sistematis dan tersusun dengan sangat terencana dipercaya mampu mengatasi masalah yang mungkin akan merugikan bank. Perencanaan dan pengendalian kredit pada PT. Bank Bukopin Cabang Manado dalam operasionalnya terealisasikan dengan sangat baik, dan mampu meminimalkan kredit. Hal ini dikarenakan perusahaan selalu mengoptimalkan perencanaan kredit sesuai dengan ketetapan perencanaan yang telah ditetapkan, dan pengendalian kreditpun selalu dimaksimalkan untuk mengurangi dan mungkin menghindari terjadinya kredit macet.

\section{KESIMPULAN DAN SARAN}

\subsection{Kesimpulan}

Berdasarkan penelitian yang dilakukan atas perencanaan dan pengendalian untuk kredit kemitraan pada PT. Bank Bukopin Manado maka dapat disimpulkan bahwa:

1. Perencanaan kredit yang dilakukan oleh PT. Bank Bukopin Cabang Manado terencana dengan sangat baik. Hal ini bisa dilihat dari anggaran kredit yang ditetapkan dari tahun 2017 sampai dengan 2018 mengalami peningkatan setiap tahunnya. Terealisasinya perencanaan pemberian kredit dengan sangat baik pada PT. Bank Bukopin Cabang Manado dikarenakan perencanaan pemberian kredit disusun berdasarkan kepada penilaian keadaan ekstern dan interen perusahaan, penyusunan data-data kredit, biaya-biaya dan dana, memperkirakan asumsi-asumsi yang mungkin terjadi, menetapkan strategi untuk menyusun target, program, dan proyek.

2. Pelaksanaan pengendalian kredit pada PT. Bank Bukopin Manado dapat dilihat dari target yang dicapainya dari tahun 2017 sampai dengan 2018 mengalami perkembangan setiap tahunnya. Terlaksananya pengendalian kredit dengan sangat baik pada PT. Bank Bukopin Cabang Manado dikarenakan bentuk dari pengendalian yang ditetapkan. Bentuk pengendalian kredit dari PT. Bank Bukopin Cabang Manado yaitu pengendalian internal dan pengendalian ekternal.

3. Perencanaan dan pengendalian kredit pada PT. Bank Bukopin Cabang Manado dalam operasionalnya mampu meminimalkan kredit macet. Hal ini dikarenakan perusahaan selalu mengoptimalkan perencanaan kredit sesuai dengan ketetapan perencanaan yang telah ditetapkan, dan pengendalian kreditpun selalu dimaksimalkan untuk mengurangi dan menghindari terjadinya kredit macet. Meskipun pada kenyataannya dalam praktek di lapangan kredit macet tidak mampu dihilangkan karena keadaan pasar dan ekonomi yang selalu berfluktuasi dan memberikan pengaruh kepada usaha nasabah, meskipun demikian perencanaan kredit dapat mengurangi dan meminimalkan terjadinya kredit macet dari debitur dimasa yang akan datang, dan untuk mengatasi kredit macet ini perusahaan harus selalu melakukan pengendalian yang optimal.

\subsection{Saran}

Berdasarkan dari kesimpulan hasil penelitian, maka saran yang diajukan adalah:

1. Perencanaan kredit dari PT. Bank Bukopin Cabang Manado dirasakan sudah cukup bagus, tetapi alangkah baiknya lagi jika perusahaan lebih mengoptimalkan lagi perencanaan kreditnya untuk mengantisipasi kemungkinan resiko yang mungkin muncul dimasa yang akan datang.

2. Pengendalian kredit nasabah bank sebaiknya tidak perlu melakukan pengawasan kredit terhadap catatan pembukuan nasabah, melainkan dengan meminta laporan keuangan yang telah diaudit oleh akuntan publik, karena akuntan publik adalah professional dalam 
pemeriksaan laporan keuangan dan dapat dipercaya hasil kerjanya, serta hal ini akan menghemat waktu dan biaya bagi pihak bank.

3. Untuk mengurangi terjadinya kredit macet, bank sebaiknya memberikan pembinaan usaha untuk nasabah yang akan mengalami kredit macet.

\section{DAFTAR PUSTAKA}

Ernawati, \& Katherina, A. I. (2017). Analisis perencanaan dan pengendalian management dalam pemberian pinjaman modal usaha pada program kemitraan usaha kecil (PKUK) Palembang: PT. Pupuk Sriwijaya. Jurnal Kompetitif Fakuktas Ekonomi, 6(2), 107121. http://univ-tridinanti.ac.id/ejournal/index.php/ekonomi/article/view/464

Firdaus, R., \& Ariyanti, M. (2017). Manajemen perkreditan bank umum, Cetakan 6. Bandung: Alfabeta.

Fernos, J. (2014). Analisis perencanaan dan pengendalian kredit studi kasus pada PT. Bank Prekreditan Rakyat (BPR) Pesisir. Jurnal Keuangan Perbankan dan Pembangunan. 2(1), 38-73. https://akbpstie.ac.id/cmsz/medias/file/4.\%20jhon\%20fernos.pdf.

Ghassani, N. (2015). Kemitraan pengembangan UMKM (Studi deskriptif tentang kemitraan PT. PJB (Pembangkit Jawa Bali) Unit Gresik pengembangan UMKM Kabupaten Gresik. Jurnal Kebijakan dan Manajemen Publik, 3(2), 142-151. http://journal.unair.ac.id/download-fullpapers-kmp16cb8512a4full.pdf.

Indrawan, R., \& Yaniwati, R. P. (2014). Metodologi penelitian kuantitatif, kualitatif, dan campuran untuk manajemen, pembangunan, dan pendidikan. Bandung: Penerbit PT Refika Aditama.

Kasmir. (2012). Manajemen perbankan, Edisi revisi. Jakarta: Rajawali Raja Grafindo Persada.

Rinaldo, R. (2016). Perencanan dan pengendalian keuangan usaha mikro kecil dan menengah pada komunitas studerpreneur STIE Ekuitas. Jurnal Dharma Bhakti STIE Ekuitas, 1(1), 42-45. http://202.93.229.166/handle/123456789/202

Rudianto. (2012). Pengantar akuntansi: konsep \& teknik penyusunan laporan keuangan. Jakarta: Erlangga.

Sugiyono. (2016). Metode penelitian kuantitatif, kualitatif dan R \& D. Bandung: Alabeta.

Suyatno, T., Chalik, H. A., Sukada, M., Ananda, C. Y. T., \& Marala, D. T. (2007). Dasardasar perkreditan, Edisi 4. Jakarta: Gramedia Pustaka Utama.

Tambunan, T. (2017). Usaha Mikro, Kecil dan Menengah, Cetakan 1. Bogor: Ghalia Indonesia.

Tambunan, T. (2012). Usaha mikro kecil dan menengah di Indonesia: Isu-isu penting. Jakarta: Lembaga Penelitian Pendidikan dan Penerangan Ekonomi dan Sosial (LP3ES).

Tuanakotta, T. M. (2014). Audit berbasis ISA (International Standards On Auditing), Cetakan 1. Jakarta: Salemba Empat.

Tohar, M. (2000). Membuka Usaha Kecil, Edisi 1. Yogyakarta: Kanisius.

Undang-Undang Nomor. 10 tahun 1998 tentang perubahan atas Undang-Undang Nomor. 7 tahun 1992 tentang Perbankan. 